Research Article

\title{
Incidence and Molecular Detection of Greening Disease in Two Citrus Cultivars in Sargodha, Pakistan
}

\author{
Ashara Sajid ${ }^{1}$, Muhammad Usman Ghazanfar ${ }^{1}$, Saeed Rauf ${ }^{2}$, Zahoor Hussain ${ }^{3}$, Salman Ahmad ${ }^{1}$ and Yasir \\ Iftikhar,**
}

${ }^{1}$ Department of Plant Pathology, College of Agriculture, University of Sargodha, Sargodha, Pakistan, 40100; ${ }^{2}$ Department of Plant Breeding and Genetics, College of Agriculture, University of Sargodha, Sargodha, Pakistan, 40100; ${ }^{3}$ Department of Horticulture, College of Agriculture, University of Sargodha, Sargodha, Pakistan, 40100

\begin{abstract}
Asian citrus greening disease is one of the leading causes of the citrus decline in many parts of the world, including Pakistan. Adequate information about disease incidence is essential for the eradication and controlling measures of disease. In this context, a survey regarding the incidence of citrus green disease (CGD) was recorded in two cultivars Kinnow (Citrus reticulate Blanco) and Mosambi (Citrus sinensis (L.) Osbeck), among significant citrus-growing areas of Sargodha district based on symptoms. Random samples of trees within orchards were scored based on characteristic symptoms like blotchy mottle, lopsided unripe fruits, and aborted seeds were observed. The highest incidence of $26 \%$ was recorded in Kot Momin, while the lowest incidence of $4.6 \%$ was found in Sahiwal. Among the cultivars, the highest disease incidence in mosambi (C. sinensis) and Kinnow (C. reticulate) was recorded 26\% in Kot Momin and 23\% in Bhalwal, respectively. Leaves samples were collected from the diseased trees to isolate DNA and to confirm greening pathogen with two primer pairs, which amplified the specific DNA ( 1160bp) and ßoperon ( 703bp) regions. The present study not only detects the molecular detection of CGD in already identified samples through the iodo-starch test but also provides reliability for quick indexing of disease in the aforesaid field. Moreover, molecular detection also revealed the (standardization) of primers used in previous and current studies. Characteristic symptoms combined with molecular detection would be useful to formulate the management strategies.

Received | December 23, 2020; Accepted | February 03, 2021; Published | March 05, 2021

*Correspondence | Yasir Iftikhar, College of Agriculture, University of Sargodha, Sargodha, Pakistan; Email: yasir.iftikhar@uos.edu.pk

Citation |Sajid, A., M.U. Ghazanfar, S. Rauf, Z. Hussain, S. Ahmad and Y. Iftikhar. 2021. Incidence and molecular detection of greening disease in two citrus cultivars in Sargodha, Pakistan. Sarhad Journal of Agriculture, 37(1): 296-301.

DOI | http://dx.doi.org/10.17582/journal.sja/2021/37.1.296.301

Keywords | Polymerase chain reaction, Huanglongbing, Symptomology, Cultivars
\end{abstract}

\section{Introduction}

O itrus is infected by several different pathogens, including fungi, prokaryotes, viruses, nematodes, and virus-like pathogens (Khan et al., 2016). Among these pathogens, the citrus greening disease is one of the most devastating and widely distributed pathogens in citrus orchards of significant citrus-growing areas of the world and Pakistan (Iftikhar et al., 2016; Saifullah et al., 2015). Citrus greening (CGD) disease is now alternatively termed as Huanglongbing (HLB) and is known with different names in different countries owing to their local languages. All the citrus cultivars are affected by this disease regardless of the rootstock. This graft transmissible disease can also be transmitted through an insect vector very efficiently (Graca, 1991; Batool et al., 2007). HLB being a century-old disease, probably originated at the end of the $19^{\text {th }}$ century in China (Batool et al., 2007; Bove, 2006). The greening disease is caused by gram-negative unculturable phloem limited bacterium (Murray and Schlifer, 1994) named Candidatus liberibacter. Jagoueix et al. March 2021 | Volume 37 | Issue 1 | Page 296 
(1996) characterized this bacterium on the basis of 16s rDNA sequence for the first time. Ha et al. (2019) have successfully cultured greening bacterium on biofilm after long and untiring efforts. This pathogen has three strains, viz., Candidatus liberibacter asiaticus (Las), Candidatus liberibacter africanum (Laf), Candidatus liberibacter americanum (Lam), based on geographical distribution and insect vector. Symptomology is the primary criterion for initial detection in the field. Characteristic symptoms of HLB under natural conditions are chlorosis, mottling (Zinc deficiency-like symptoms), aborted seeds in the fruit, and lopsided fruit (Bove 2006; Saifullah et al., 2015). At maturity, citrus fruits from the styler end remain green while; sometimes it remains green at the peduncular end, which is known as "color inversion" or "red nose" (Akhtar and Ahmed, 1999; Batool et al., 2007).

Kinnow (Citrus reticulate) and Mosambi (Citrus sinensis (L.) Osbeck) are the most susceptible citrus cultivars (Knapp et al.,2004). Molecular markers have been employed for the detection of CGD after the symptomology. These markers characterized the CGD on the basis of 16s rDNA and $\beta$ operon regions. The PCR method detected the liberibacter species in citrus samples by 1160 bp fragment amplification (Jagoueix et al., 1996). Different molecular and serological techniques have also been developed and optimized. Recently, established and advanced techniques like molecular, biological, and serological assays for pathogen detection have been reviewed (Iftikhar et al., 2016; Ding et al., 2020). PCR and qPCR have been engaged for the detection of two markers, one for the 16s rDNA (OI1 and OI2C) and the other for Las (Boperon) A2/J5 (Razi et al., 2014; Yaqub et al., 2017). Correct and quick detection of a pathogen provides a base to formulate the management strategies for HLB. The present study is a combination of CGD symptomatic and molecular diagnosis in all the tehsils of Sargodha district.

\section{Materials and Methods}

\section{Incidence of CGD}

Two commercially grown citrus cultivars, viz., Kinnow and Musambi were targeted for their citrus orchards' availability. Citrus samples infected with CGD were collected on the basis of characteristics symptoms (Saifullah et al., 2015) from the citrus orchards of all the tehsils of district Sargodha viz., Sargodha,
Bhalwal, Sillanwali, Sahiwal, Shahpur, Bhera, and Kot Momin. A total of 150 samples/tehsil with apparent symptoms were monitored for the record of disease incidence. Leaves from the marked citrus trees were collected and pooled for PCR detection and confirmation. Disease incidence was calculated as follows;

Disease Incidence $(\%)=\frac{\text { Number of Infected trees }}{\text { Total number of trees observed }} \mathrm{X} 100$

\section{Molecular detection}

Polymerase chain reaction: The polymerase chain reaction was used for molecular detection from the pool of leaves samples. DNA was extracted by using a DNA extraction kit (GF-1 Vivantis Malaysia with provided standard protocol). Two primer sets (OI1 GCGCGTATGCAATACGAGCGGCA Forward and OI2c GCCTCGCGACTTCGCAACCCAT Reverse) described by (Jagoueix et al., 1996) and (A2 TATAAAGGTTGACCTTTCGAGTTT Forward and J5 ACAAAAGCAGAAATAGCACGAACAA Reverse) described by Hocquellet et al. (1999) were used to amplify $16 \mathrm{~s}$ rDNA and $\beta$ operon respectively from the processed samples of citrus. A total of $25 \mu 1$ PCR reaction mixture for $1 \mathrm{X}\left(\mathrm{d}_{2} \mathrm{H}_{2} \mathrm{O} 14.3 \mu \mathrm{l}\right.$; Buffer 10X 2.5 $\mu \mathrm{l}$; MgCl2 (25mM) $2.0 \mu \mathrm{l}$; dNTPs $(2.0 \mathrm{mM})$ $2.0 \mu \mathrm{l}$; Primers F $(1 \mu \mathrm{M}) 1.0 \mu \mathrm{l}$; Primers R $(1 \mu \mathrm{M}) 1.0$ $\mu 1$; Taq DNA Polymerase $0.2 \mu \mathrm{l}$ and Template DNA $2.0 \mu \mathrm{l})$ was used. The conditions for PCR were; initial denaturation at $94^{\circ} \mathrm{C}$ for 2 minutes $(1$ cycle $) ; 94^{\circ} \mathrm{C}$ for 30 seconds, $58^{\circ} \mathrm{C}$ for 1 minute and $72^{\circ} \mathrm{C}$ for 1 minute (35 cycles); final extension at $72^{\circ} \mathrm{C}$ for 10 minutes (1 cycle). The PCR product after the reaction was held at $4^{\circ} \mathrm{C}$ for infinity.

\section{Gel electrophoresis}

The PCR products were analyzed by gel electrophoresis using $0.8 \%$ agarose in $0.5 \mathrm{X}$ TBE buffer. Ethidium bromide was used to stain the PCR product. The gel was run at 80 volts for 45 minutes.

\section{Results and Discussion}

\section{Symptomology and incidence of CGD}

The characteristic symptoms were observed during the survey (Figure $1 \mathrm{~A}-\mathrm{E}$ ). Blotchy mottling and chlorosis were observed in the leaves samples (Figure 1C, D). Aborted seeds (Figure 1E), lopsided fruits, and full or half green fruits were observed (Figure $1 \mathrm{~A}, \mathrm{~B})$. Our results regarding symptomology were in 
accordance with Batool et al. (2007). They reviewed the characteristic symptoms like yellowing of leaves, Lopsided fruits, blotchy mottle, aborted seeds, and unripe fruits (Fruit remain green). Similar results have also been reported by (Saifullah et al., 2015; Inoue et al., 2020). Yellowing of leaves, blotchy mottling, upright growth of CGD infected trees, and lopsided fruits were observed during our study which is in accordance with McCollum and Baldwin (2017). As disease progresses, the leaves drop, shoots remain stunted later on the branches die gradually (Tipu et al., 2020). Symptomology of CGD-affected fruits has also been reviewed by (Dala-Paula et al., 2019). Regarding the incidence in different tehsils of Sargodha district (Table 1), the highest incidence of CGD 24\% was recorded in Kot Momin with followed by Bhalwal 22\%, whereas the least incidence was recorded in Sahiwal tehsil with 4.6\%. Similarly, Mosambi (Citrus sinensis (L.) Osbeck) showed the highest incidence $26 \%$ in Kot Momin and the least incidence $8 \%$ was recorded in Sahiwal. Kinnow had the highest incidence of $23 \%$ in Kot Momin at par with Bhalwal. The least incidence, of CGD in Kinnow (C. reticulate), was 3\% in Sahiwal. CGD has been reported in around 44 countries of Asia and America (Ajene et al., 2019). Initially, the incidence of CGD in Pakistan was recorded by Catara et al. (1991) and Akhtar and Ahmed (1999) in KPK and the Punjab. They recorded a high incidence of CGD in Kinnow $22 \%$, Sweet orange $25-40 \%$ in the Punjab. They mainly collected the citrus samples from Sargodha region. The results of our studies are also in agreement with their study. Similar types of symptoms were observed during the sample collections. The CGD was confirmed in $41 \%$ of citrus samples collected from different orchards in the Punjab during a survey (Razi et al., 2011). CGD incidence of $42 \%$ in kinnow and sweet orange was recorded by Zafarullah et al. (2016). Saifullah et al. (2015) recorded the disease incidence ranging $8-11 \%$ in all the tehsils of Sargodha district. They also observed characteristics symptoms of CGD such as mottling, zinc deficiency like symptoms, lopsided fruit and aborted seeds. Our results are also in accordance with the previous studies. We also observed the same type of symptoms and trend in CGD incidence. A different number of samples were collected in different months of a year and found positive for CGD detection. High incidences were found in February, April, and May (Razi et al., 2014). Therefore, symptomology plays a vital role in the early detection of CGD in the field.

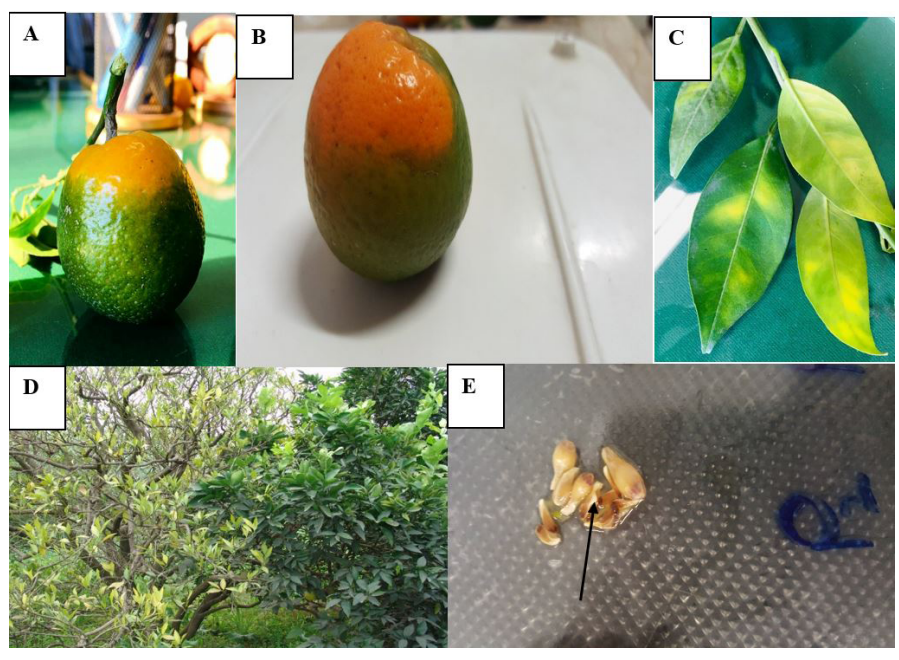

Figure 1: $(A$ and $B)$ : $C G D$ infected lopsided and half green fruit; $(C$ and D): Mottle leaf and Chlorosis on tree; (E): Aborted seeds.

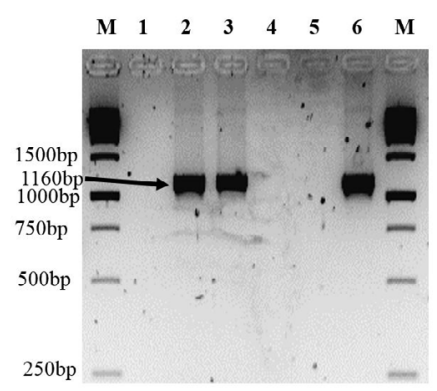

2A: Primer OI1/OI2C

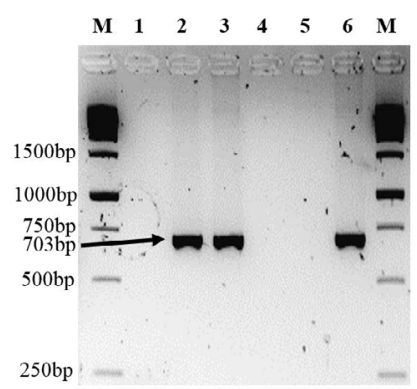

2B: Primer A2/J5
Figure 2: $(A$ and $B)$ Lane $M=1 k b D N A$ Ladder, Lane 1: Negative Control $\left(\mathrm{dH}_{2} \mathrm{O}\right)$, Lanes $4,5=\mathrm{DNA}$ samples from healthy trees (asymptomatic); Lanes 2, 3= DNA samples from CGD infected (Symptomatic plants) (Kinnow and Mosambi, respectively). Lane $6=$ Positive Control (Already confirmed CGD sample).

Table 1: Disease incidence in varieties at different places.

\begin{tabular}{lllll}
$\begin{array}{l}\text { Sr. } \\
\text { No. }\end{array}$ & Tehsil & $\begin{array}{l}\text { Disease incidence } \\
(\%) \text { (Over all) }\end{array}$ & $\begin{array}{l}\text { Disease incidence in } \\
\text { varieties (\%) } \\
\text { Kinnow Mosambi }\end{array}$ \\
\hline 1 & Sargodha & 18 & 18 & 16 \\
2 & Bhalwal & 22 & 23 & 20 \\
3 & Kot momin & 24 & 23 & 26 \\
4 & Shahpur & 14 & 16 & 10 \\
5 & Sillanwali & 14 & 14 & 14 \\
6 & Bhera & 10 & 10 & 10 \\
7 & Sahiwal & 4.6 & 3 & 8 \\
\hline
\end{tabular}

\section{Molecular detection}

Due to the inability of "CLas" to be cultured in vitro conditions (Ghosh et al.,2018), it is very much difficult to study ecology, epidemiology, and management of this pathogen (Kokane et al., 2020). PCR confirmed the greening pathogen in leaves samples of both citrus cultivars, including Kinnow and Mosambi (Figure 2A and $2 \mathrm{~B}$ ). DNA of citrus cultivars was amplified by two 
primer pairs, which amplified the PCR products at the desired size of $\sim 1160 \mathrm{bp}$ and $\sim 703 \mathrm{bp}$, respectively.PCR product size has been confirmatory through previous literature that also reported similar band sizes using their respective primer pairs (Chohan et al., 2007; Zafarullah et al., 2016; Yaqub et al., 2017). The primer used in these studies is based on the amplification of bacterial 16s rDNA and $\beta$ operon regions. Citrus greening disease in citrus orchards of North-Eastern Indian region was also confirmed through PCR (Das et al., 2007), which was also recently reported by Kokane et al. (2020). The identified isolates of CLas from Bhutan reported by Ghosh et al. (2020) were analogous to Indian isolates of North-East regions based on CLIBASIA_01645 locus. Davi et al. (2020) detected HLB in citrus species, viz., C. reticulate, Citrus jambhiri, Citrus maxima, Citrus medica, Citrus macroptera using $16 \mathrm{~S}$ rRNA amplicon fragment and found that its resemblance with " $\mathrm{Ca}$. Liberibacter asiaticus" sequenced from the rest of the World. A high CLas DNA level in the HLB symptomatic leaves was detected through qPCR (Zhang et al., 2020). Primer A2/J5 was used to distinguish between CLas and CLaf. Specific amplification of $r$-protein genes directly identified the two species based on DNA band size (Ruangwong and Akarapisan, 2006). Specific amplification by CLas was 703 bp, while CLaf produced a band of $669 \mathrm{bp}$ size (Hocquellet et al., 1999). Specific amplification of 703bp was observed in all infected samples from HLB-CM using A2/J5 primers (Ruangwong and Akarapisan, 2006). They also recorded that no amplification was found in healthy or asymptomatic plants. Molecular-based detection of pathogens, including Huanglongbing, has been robust and could detect pathogens at very low intensity even before the symptoms' physical appearance (Iftikhar et al., 2016). Therefore, it is recommended that molecular methods should be employed for the sanitation of citrus nurseries to reduce disease incidence and the establishment of disease-free new orchards.

\section{Conclusions and Recommendations}

Citrus greening disease incidence ranged between 4.6 - 24\% among the mandarin and mousambi cultivars in various districts of the central Punjab. The disease may be recognized on the basis of its characteristic symptoms and may threaten the sustainability of the regions' citriculture. Regardless of symptoms, molecular markers provide us an efficient tool for the detection of the pathogen. The present study used molecular markers that amplified 16s rRNA of pathogen visualized through a PCR product of 703 bases compared to no amplification in diseasefree plants. Thus molecular markers may be a recommended strategy in symptomless plants and in the sanitation of nursery to reduce further spread of this disease.

\section{Acknowledgments}

The authors are highly thankful to ORIC for the financial support of the Project entitled "Monitoring of devastating effects of Citrus greening disease (CGD) in the declining orchards of Sargodha and its management through micronutrients to help the citrus industry." The authors presented research work as a part of a Doctoral dissertation in the Department of Plant Pathology, College of Agriculture, SU.

\section{Novelty Statement}

This is paucity of data on molecular characterization of HLB in Pakistan. This study will strengthen the knowledge about the diversity of this pathogen in Punjab, Pakistan.

\section{Author's Contribution}

AS conducted the experiments. MUG was the major supervisor and conceived the idea and monitored the execution of work. SR helped and monitored the molecular work. $\mathrm{ZH}$ was the CO-PI of the project and helped in collection of samples and manuscript writeup. SA Proof read and improved the manuscript. YI was the principal investigator of the project and provided the materials for experimentation.

\section{Conflict of interest}

The authors have declared no conflict of interest.

\section{References}

Ajene, I.J., F. Khamis, B. van Asch, G. Pietersen, B.A. Rosowo, S. Ekasi and S.Mohammed.2020. Habitat suitability and distribution potential of Liberibacter species (Candidatus Liberibacter asiaticus and Candidatus Liberibacter africanus) associated with citrus greening disease. Divers Distrib., 26: 575-588. https://doi.org/10.1111/ ddi.13051 
Akhtar, M.A. and I. Ahmad. 1999. Incidence of citrus greening disease in Pakistan. Pak. J. Phytopath., 11: 1-5.

Batool, A., Y. Iftikhar, S.M. Mughal, M.M. Khan, M.J. Jaskani, M. Abbas and I.A. Khan. 2007. Citrus greening disease-a major cause of citrus decline in the world-a review. Hort. Sci.(Prague). 34: 159-166. https://doi.org/10.17221/1897HORTSCI

Bové, J.M., 2006. Huanglongbing: A destructive, newly-emerging, century-old disease of citrus. J. Plant Pathol., 1: 7-37.

Catara, A., A. Azzaro, M. Davino, V. Grimaldi, M. Hussain, M. Saleem and M.S. Mirza. 1991. A survey of tristeza and greening in Punjab, Pakistan. In: BRLANSKY R. H. Lee, R.F and L.W. Timmer (eds), Proc. of the 11th Conf. of the Intl. Organ. of Citrus Virologists (IOCV). CA, Riverside. Pp. 166-170

Chohan, S.N., R. Qamar, I. Sadiq, M. Azam, P. Holford and A. Beattie. 2007. Molecular evidence for the presence of Huanglongbing in Pakistan. Aust. Plant Dis. Notes, 2: 37-38. https://doi.org/10.1071/DN07019

Dala-Paula, B.M., A. Plotto, J. Bai, J.A. Manthey, E.A. Baldwin, R.S. Ferrarezi and M.B.A. Gloria. 2019. Effect of huanglongbing or greening disease on orange juice quality. A review. Front. Plant Sci., 9: 1976. https://doi. org/10.3389/fpls.2018.01976

Das, A.K., C.N. Rao and S. Singh. 2007. Presence of citrus greening (Huanglongbing) disease and its psyllid vector in the North-Eastern region of India confirmed by PCR technique. Curr. Sci., 92(12): 1759-1763.

Devi, E.J., R.K. Labala, R. Modak, N.S. Singh, N.S and H.S. Devi. 2020. Molecular detection of "Candidatus Liberibacter asiaticus" causing HLB in Manipur and correlation of its incidence with elevation. Trop. Plant Path. 45(6): 658667. https://doi.org/10.1007/s40858-02000392-3

Ding. F., Shu-ang Peng and J.S. Hartung. 2020. Enhanced Serologically Based Detection of Liberibacters Associated with Citrus Huanglongbing. Plant Dis., 105(6): 15841588. https://doi.org/10.1094/PDIS-12-192679-SC

Ghosh, D.K., A. Kokane, S. Kokane, J. Tenzin, M.G., Gubyad, P. Wangdi and S. Gowda. 2020. Detection and molecular characterization of
'Candidatus Liberibacter asiaticus' and Citrus tristeza virus associated with citrus decline in Bhutan. Phytopathology, (ja). https://doi. org/10.1094/PHYTO-07-20-0266-R

Ghosh, D.K., M. Motghare and S. Gowda. 2018. Citrus greening: overview of the most severe disease of citrus. Adv. Agric. Res. Tech. J., 2: 83100.

Graca, J.D., 1991. Citrus greening disease. Ann. Rev. Phytopathol., 29: 109-136. https://doi. org/10.1146/annurev.py.29.090191.000545

Ha, P.T., R. He, N. Killiny, J.K. Brown, A. Omsland, D.R. Gang and H. Beyenal. 2019. Host-free biofilm culture of Candidatus Liberibacter asiaticus, the bacterium associated with Huanglongbing. Biofilm, 1: 100005. https:// doi.org/10.1016/j.bioflm.2019.100005

Hocquellet, A., P. Toorawa, J.M. Bové and M. Garniner. 1999. Detection and identification of the two Candidatus Liberobacter species associated citrus huanglongbing by PCR amplification of ribosomal protein genes of the operon. Mol. Cell.Probes., 13:373-379. https:// doi.org/10.1006/mcpr.1999.0263

Iftikhar, Y., S. Rauf, U. Shahzad and M.A Zahid. 2016. Huanglongbing: Pathogen detection system for integrated disease management-A review. J. Saudi Soc. Agric. Sci., 15: 1-11. https://doi.org/10.1016/j.jssas.2014.04.006

Inoue, H., S. Yamashita-Muraki, K. Fujiwara, K. Honda, H. Ono, T. Nonaka and Y. Masaoka. 2020. $\mathrm{Fe} 2+$ ions alleviate the symptom of citrus greening disease. Int. J. Mol. Sci., 21(11): 4033. https://doi.org/10.3390/ijms21114033

Jagoueix, S.,J.M. Bové, and M. Garnier. 1996. PCR detection of the two 'Candidatus' liberobacter species associated with greening disease of citrus. Mol. Cell. Probes, 10: 43-50. https://doi. org/10.1006/mcpr.1996.0006

Khan, N., A.A. Khan, M. Ahmad, M. Nouman and B. Islam. 2016. Evaluation and screening of sweet orange cultivars for vegetative growth and citrus canker. Sarhad J. Agric., 32(2): 121-126. https://doi.org/10.17582/journal. sja/2016/32.2.121.126

Knapp, J.L., S. Halbert, R. Lee, M. Hoy, R. Clarkand M. Kesinger. 2004. The Asian citrus psyllid and citrus greening disease. Citrus Ind., 79: 1028-1029.

Kokane, S.B., S. Bhose, A. Kokane, M. Gubyad and D.K. Ghosh. 2020. Molecular detection, 
identification, and sequence analysis of 'Candidatus Liberibacter asiaticus' associated with Huanglongbing disease of citrus in North India. 3 Biotech., 10(8): 1-14. https://doi. org/10.1007/s13205-020-02334-x

McCollum, G. and E. Baldwin. 2017. Huanglongbing: devastating disease of citrus. Horticult. Rev. 44: 315-361

Murray, R.G.E. and K.H. Schleifer. 1994. Taxonomic notes: A proposal for recording the properties of putative taxa of procaryotes. Int. J. Syst. Bacteriol., 44: 174-176. https://doi. org/10.1099/00207713-44-1-174

Razi, M.F., I.A. Khan and M.J. Jaskani. 2011. Citrus plant nutritional profile in relation to Huanglongbing prevelance in Pakistan. Pak. J. Agric. Sci., 48(4): 299-304.

Razi, MF., M.L. Keremane, C. Ramadugu, M. Roose, I.A. Khan and R.F. Lee. 2014. Detection of citrus huanglongbing-associated 'Candidatus Liberibacter asiaticus' in citrus and Diaphorina citri in Pakistan, seasonal variability, and implications for disease management. Phytopath, 104: 257-268. https://doi. org/10.1094/PHYTO-08-13-0224-R

Ruangwong, O. and A. Akarapisan. 2006. Detection of Candidatus Liberibacter asiaticus causing Citrus Huanglongbing disease. J. Agric. Technol., 2(1): 111-120.

Saifullah, I.U., Haq, Y. Iftikhar, S.A. Khan, M.J. Jaskani, Samiullah and R.M.S. Tariq. 2015.
Quick Indexing of Huanglongbing on the basis of symptomology and Iodo-starch test in relation to environmental factors. Pak. J. Agric. Sci., 52(4): 1005-1009

Tipu, M.M.H., M.M. Rahman, M.M. Islam, F.E. Elahi, R.Jahan and M.R. Islam. 2020. Citrus greening disease (HLB) on Citrus reticulata (Mandarin) caused by Candidatus Liberibacter asiaticus in Bangladesh. Physiol. Mol. Plant Path., 112 (2020): 101558. https://doi. org/10.1016/j.pmpp.2020.101558

Yaqub, MS., A.K. Iqra, U. Muhammad and A.R. Iqra. 2017. Molecular detection of candidatus liberibacter asiaticus, the causal organism of Huanglongbing (citrus greening) in Paisalabad, Pakistan for huanglongbing management. Pak. J. Agric. Sci., 54(1): 21-26. https://doi. org/10.21162/PAKJAS/17.4455

Zafarullah, A., N. Shagufta and S. Faiza. 2016. Detection and Molecular characterization of Candidatus Liberibacter spp. causing Huanglongbing in indigenous citrus cultivars in Pakistan. Pak. J. Bot., 48(5): 2071-2076.

Zhang, X.H., N. Pizzo, M. Abutineh, X.L. Jin, S. Naylon, T.L. Meredith, L. West and J.M. Harlin. 2020. Molecular and cellular analysis of orange plants infected with Huanglongbing (citrus greening disease). Plant Gr. Reg., 92: 333-343. https://doi.org/10.1007/s10725020-00642-z 